“Historical Studies on Mortality,” special issue, Canadian Studies in Population 39, no. 3-4 (2012): 125-126.

\title{
The Plundered Planet: Why We Must_and How We Can- Manage Nature for Global Prosperity
}

\author{
by Paul Collier \\ New York, NY: Oxford University Press, 2010 \\ ISBN: 978-0195395259 \\ Hardcover $\$ 24.95,288$ pp.
}

\author{
Reviewed by Donald Spady \\ Faculty of Medicine \& Dentistry and School of Public Health \\ University of Alberta, Edmonton (Canada) \\ dspady@ualberta.ca
}

Paul Collier's book The Plundered Planet: Why We Must—and How We Can-Manage Nature for Global Prosperity, follows his earlier book, The Bottom Billion, which described the plight of the worlds poorest peoples. In the current book Collier asserts that "The countries of the bottom billion have one lifeline: nature.", and that "Technology turns nature into an asset... [and]...gives those assets the potential to be valuable to society." His overall theme is "how the natural world $[\ldots]$ can be harnessed to transform these poor societies without placing unreasonable demands on the rest of us."

The book consists of 11 chapters divided into 5 parts. Part I describes the dilemma of the bottom billion, emphasizing those living in Africa, and the potential of Africa's natural resources to promote economic growth and development. Part II outlines a four step approach a resource rich but economically poor country could follow to exploit its resources most effectively. In summary, these steps are: finding the asset; deciding who captures its value; deciding how much to spend on acquiring other assets; and deciding what to do with the remainder of the proceeds. Collier summarizes the obligations of today's society to posterity by stating: "We are not curators of the natural world, preserving nature as an end in itself. [...] We are custodians of the value of natural assets. We are ethically obliged to pass on to future generations the equivalent value of the natural assets that we were bequeathed by the past." He demonstrates clearly the necessity for well crafted, enforceable—and enforced—regulations regarding resource exploitation and the disposition of the proceeds so as to provide equitable benefits to all of a nation's citizens. Parts III and IV provide examples of possible approaches to resource exploitation; Part III explores fisheries while Part IV addresses agriculture. Since world fisheries are close to exhaustion, he suggests that the natural assets of the oceans be managed by the United Nations, which could then auction off fishing rights each year, thus ensuring a level of fisheries sustainability. Regarding agriculture, Collier embraces the use of genetically modified crops and large-scale commercial agriculture and dismisses the use of "peasant..." agriculture, which he links_-pejoratively—with organic agriculture and the environmental philosophies of Prince Charles. Part V introduces the Natural Resource Charter, which Collier has spear-headed and the purpose of which is to advocate for appropriate resource development and to cripple the efforts of unscrupulous exploiters. He ends by discussing whether governments or local citizenry can best achieve desired change; arguing that governments may be too dysfunctional to be effective change-makers and local individuals and groups may be better. However, success depends on leadership and an informed and motivated citizenry that will have to navigate a minefield of competing interests.

This interesting book is worth reading if only to get the perspectives of a highly regarded economist with expertise in African development issues. The economic aspects of many of Collier's suggestions for resource exploitation appear sensible to me, but I am not an economist. The bottom billion face overwhelming problems, and I think Collier genuinely wants to improve their lot. 
Will his prescription work? No. By choice, chance, or ignorance, Collier seems to have ignored a key factor: nature needs nature. Perhaps I am short-changing him, but I used a Kindle to read this book and scanned it for words that might express Collier's awareness of nature's role in maintaining the ecological integrity of Earth; I found none. Instead, he writes: "We are not curators of the natural world, preserving nature as an end in itself. [...] We are custodians of the value of natural assets," and "Technology turns nature into an asset." He seems to assess nature only as material that can be turned into "value." A problem arises in that the "value" Collier wants to create comes from the same nature that Earth requires to maintain its, and hence our, fundamental life support systems. Imagine cutting off a huge tree limb, planning to sell the wood, and overlooking the fact that you are standing on the limb distal to the cut. Not too smart.

Collier's theme is "not how the natural world can be preserved $[. .$.$] in itself" but rather how we can harness the$ natural world to transform poor societies "without placing unreasonable demands on the rest of us." It is possible that he does not see the issue of ecological integrity as a critical problem. The implicit assumptions he makes-the natural world can meet the demands of newly growing economies; the resource demands of "the rest of us" are currently not unreasonable; and the natural world can function to maintain life indefinitely under current conditionsseem to support this conclusion. But these assumptions are all false.

Improving the lot of the bottom billion - who have a 0.5-Earth footprint, which will inevitably increase with development - without placing "unreasonable demands on the rest of us" (with a 3-Earth footprint) is unattainable. The Earth's biocapacity has already been exceeded; we are using more resources than can be replaced. Continued exploitation is not the answer; there must be another way.

Equally dubious is Collier's pledge to "pass on to future generations the equivalent value of the natural assets that we were bequeathed..." I tried to determine what his "equivalent value" of nature was; I found only financial investments, physical infrastructure, and optimism. None of these replace what nature must provide to maintain life. Financial investments are ephemeral and fickle, physical infrastructure lasts only so long, and ultimately fails, and optimism is often conflated with technology or, more subtly, denial. Posterity needs many things, but fundamentally it needs nature's services. These cannot be replaced, nor can they be "managed." Humanity must learn the hard lesson that to reach its goals it must work within the laws and constraints of physics and biology and economists must craft their plans within these same bounds. Obviously economics is important, but these examples of economic arrogance, of considering the primacy of economics but not the essentiality of ecological integrity, are off-putting.

Collier argues that traditional agriculture cannot feed the world; large-scale agriculture is required. However, which in the long run would do the most harm to humanity: possible transient, local, food shortages, or permanently crippled — in any human timeframe-global life support systems? These questions demand resolution. (Neither does Collier address the bigger question — the fantasy, the requirement, the abhorrence to "the rest of us" (!)—of both "poles" moving toward the middle, of raising the living standards of the bottom billion while the "rest of us" move from a 3-Earth to a 1-Earth lifestyle. Fortunately, resolving this mandatory question is not the task of this review.) Large-scale agriculture is clearly successful, but requires huge amounts of water, fossil fuels, fertilizers, and pesticides. These requirements are demonstratively ecologically destructive; they make commercial agriculture more vulnerable to disease, resource depletion, and climate change, and thus possibly less resilient than traditional agriculture. In particular, they are vulnerable to the imminent likelihood of peak oil which will raise the price and eventual scarcity of fossil fuels and petrochemically based fertilizers and pesticides. Collier recognizes this latter possibility, but says the problem will be resolved by technology. Is this posterity's equivalent value of optimism? Finally, large-scale agriculture is capital intensive and out of reach of most small-scale farmers. Collier suggests they move to cities where they can contribute to economic growth, a concept with its own problems of sustainability and credibility. Traditional agriculture cannot be dismissed out of hand; it provides employment, uses fewer resources and simpler technology, and is cheaper. It is local and involves farmers and land-owners committed to and knowledgeable about their property. It is not glamorous, it is hard work, but, properly done, it can be competitive in food production and may be more resilient to the vagaries of nature and society. Large-scale agriculture has its place and role, but it is wrong to dismiss what has been commonly done for generations and which could very likely be improved upon with some directed research.

If you want to gain insight into the social, economic, and political aspects of resource management, and more particularly into how to consider the fiscal consequences of resource exploitation in a poor country, this book is interesting and useful. Many readers may want to pursue some of his assertions, but unfortunately the references provided are scant and relate only to Collier's own work; there are no links to other authors, or to other viewpoints. If you want to gain insight into the dilemma of meeting the needs of the bottom billion and at the same time preserving the ecological integrity of Earth and, thus, of humanity... Well, that book has yet to be written. 